\title{
Cardiovascular and hypokalaemic effects of inhaled salbutamol, fenoterol, and isoprenaline
}

\author{
JULIAN CRANE, CARL BURGESS, RICHARD BEASLEY \\ From the Department of Medicine, Wellington School of Medicine, Wellington, New Zealand
}

\begin{abstract}
The cardiovascular and hypokalaemic effects of equal doses of inhaled fenoterol, isoprenaline and salbutamol were compared in eight healthy male volunteers, in a double blind, placebo controlled study. Increasing doses of 400,600 , and $800 \mu \mathrm{g}$ were given from a metered dose inhaler at 15 minute intervals, followed by measurements of heart rate, blood pressure, total electromechanical systole (as a measure of inotropic response), QTc interval, and plasma potassium concentration. After repeated inhalation, fenoterol resulted in significantly greater chronotropic, electrocardiographic, and hypokalaemic effects than either isoprenaline or salbutamol. The maximum inotropic effect of fenoterol was similar to that of isoprenaline.
\end{abstract}

\section{Introduction}

As a result of concern that isoprenaline may have been responsible for the rise in asthma mortality in several countries in the $1960 \mathrm{~s}^{1}$ several beta ${ }_{2}$ adrenergic agonist drugs were developed. Inhaled beta, agonists are now the most widely used treatment for asthma in New Zealand. ${ }^{2}$ Although these agents have been shown to have a greater selectivity ratio $^{3}$ (that is, ratio of bronchodilator effect to chronotropic effect for a given intravenous dose), little work has been done to compare their cardiac effects with those of isoprenaline administered by the inhaled route in man. Since their introduction there have been reports of arrhythmias in some patients ${ }^{45}$ and aggravation of angina in those with ischaemic heart disease. ${ }^{67}$

Over the last decade mortality from asthma has again increased in some countries, in particular New Zealand. ${ }^{8}$ As a result of detailed investigations into the causes of this increase in mortality in New Zealand, one of the recommendations of the Ministerial Asthma Task Force was that "the relationship between the trends in asthma mortality and anti-asthma medication requires further investigation." 9 An International Asthma Mortality Task Force has subsequently recommended that "further information is needed about the deleterious side effects of antiasthma medications used alone and in combination."

Address for reprint requests: Dr J Crane, Department of Medicine, Wellington School of Medicine, PO Box 7343, Wellington South, Wellington, New Zealand.

Accepted 6 December 1988
In response to these recommendations we have compared the cardiovascular effects of isoprenaline with those of fenoterol, salbutamol, and placebo. Salbutamol became available in New Zealand in 1970 and fenoterol in 1976, and these two agents are the most commonly prescribed beta ${ }_{2}$ adrenergic agonist aerosol preparations in New Zealand. Because measurement of heart rate and blood pressure may not adequately reflect the extent of the haemodynamic changes due to inhaled beta ${ }_{2}$ adrenergic agonists, ${ }^{11}$ we have also measured changes in electromechanical systole $\left(\mathrm{QS}_{2} \mathrm{I}\right)$ as a measure of inotropic response and in QTc as a measure of electrophysiological effect. We have also examined the effect of these agents on plasma potassium concentration, in view of the recent finding that inhalation of beta ${ }_{2}$ adrenergic agonists may cause substantial hypokalaemia, ${ }^{12}$ and that fenoterol has a greater propensity to cause hypokalaemia than salbutamol. ${ }^{13}$

\section{Methods}

\section{SUBJECTS}

We studied eight healthy non-smoking male volunteers with a mean age of 33 (range 27-41) years. All had a normal resting electrocardiogram (ECG), no history of cardiovascular, respiratory, or thyroid disease, and no known sensitivity to sympathomimetic agents. No subject was receiving regular medication. The study was approved by the research ethical committee of the Wellington Hospital Board, and informed written consent was obtained from each subject. 
PROTOCOL

On four separate occasions, subjects attended the laboratory in the fasted state and rested supine for 10 minutes after insertion of an indwelling venous catheter for sampling. Control measurements of total electromechanical systole $\left(\mathrm{QS}_{2}\right), \mathrm{ECG}$, and blood pressure, were made, and blood was taken for measurement of plasma potassium concentrations. The subjects received either salbutamol, fenoterol, isoprenaline, or placebo, in doses of 400,600 and $800 \mu \mathrm{g}$ at 15 minute intervals. The treatments were administered randomly according to a balanced Latin square design, blinded to both subject and investigator. Subjects remained supine throughout the study except during administration of the aerosol. The cardiovascular measurements were made five and 15 minutes after inhalation of each dose. Plasma was sampled 15 minutes after each dose and plasma potassium concentraton was measured by flame photometry. The study was terminated if a subject developed a heart rate of over 110 beats/min or systolic blood pressure of over $150 \mathrm{~mm} \mathrm{Hg}$.

All subjects were medical personnel familiar with the use of metered dose inhalers and all were instructed in a standard technique of inhalation. The inhaler was held in the mouth and subjects were asked to inhale slowly from functional residual capacity to total lung capacity, and to actuate the inhaler just after the onset of inspiration. They were instructed to hold their breath for three seconds after inhalation and then to exhale slowly. The study was not begun until the investigator was satisfied with the adequacy and reproducibility of the inhaler technique. $\mathrm{QS}_{2}$ was measured as previously described,${ }^{14}$ and corrected for heart rate according to an equation developed in our laboratory: $\mathrm{QS}_{2} \mathrm{I}=\mathrm{QS}_{2}+1.2 \times \mathrm{HR}\left(\mathrm{QS}_{2} \mathrm{I}\right.$ is the $\mathrm{QS}_{2}$ index, corrected for heart rate) ${ }^{15}$ Briefly, measurement is made from the onset of the $Q$ wave of the high speed ECG to the initial high frequency recording of the second heart sound. The ECG and phonocardiogram are recorded photographically on paper at $100 \mathrm{~mm} / \mathrm{s}$ from an oscilloscope trace. From the ECG the QT interval was measured by extrapolating the descending slope of the $\mathrm{T}$ wave to the baseline (horizontal line joining the P-P interval). The QT interval was corrected for heart rate by means of the Bazett formula. ${ }^{16}$ Blood pressure was mesured with an automatic cuff (Vita-Stat).

\section{ANALYSIS}

Statistical analysis was undertaken by means of the SAS statistical package. A fourway analysis of variance for repeated measures ${ }^{17}$ was performed, on change from control data, with subject, treatment, time and group effects being analysed. The significance level was adjusted for multiple comparisons by using
Bonferroni's inequality ${ }^{18}$ ( $p \leqslant 0 \cdot 05 /$ number of comparisons). Hence a probability value of $p<0.0028$ was considered significant for changes in plasma potassium, and $\mathrm{p}<0.0014$ for all other values.

\section{Results}

There were no significant differences between the subjects' control measurements on any of the four study days (table 1). For fenoterol and isoprenaline, the measurements that followed the $800 \mu \mathrm{g}$ dose represent the mean for seven subjects, as one subject was withdrawn on both occasions after an acute rise in sytolic blood pressure to $>160 \mathrm{~mm} \mathrm{Hg}$ after the $600 \mu \mathrm{g}$ dose. The change in heart rate and $\mathrm{QS}_{2} \mathrm{I}$ from baseline for the three doses of beta agonist and placebo are shown in table 2 and changes in blood pressure in table 3 with the significance values.

Heart rate Fenoterol caused a greater increase in heart rate than either isoprenaline or salbutamol from 20 to 45 minutes.

$Q S_{2} I$ For the three beta agonists the mean maximum effect was observed five minutes after each dose. Fenoterol had a significantly greater effect than isoprenaline at 30 and 45 minutes or salbutamol at 20 , 35 , and 45 minutes. Isoprenaline had a significantly greater effect than salbutamol at 20 and 35 minutes.

Blood pressure Fenoterol had a significantly greater systolic pressor effect than isoprenaline at 30 minutes or salbutamol from 20 to 45 minutes. Isoprenaline increased systolic pressure significantly more than salbutamol at 35 minutes. Both salbutamol and fenoterol caused a greater fall in diastolic blood pressure at 45 minutes than isoprenaline.

QTc (fig 1) By comparison with placebo, fenoterol increased the QTc interval significantly from $15 \mathrm{~min}$ utes onwards, salbutamol at 35 and 45 minutes only, and isoprenaline at 30 and 45 minutes. The increases following fenoterol were greater than those that followed isoprenaline and salbutamol at 20,35, and 45 minutes.

Plasma potassium (fig 2) By comparison with

Table 1 Mean (SEM) control values in eight subjects before the treatments

\begin{tabular}{lcclc}
\hline Unit & Placebo & Fenoterol & Isoprenaline & Salbutamol \\
\hline Heart rate & $67 \cdot 4(4 \cdot 3)$ & $63 \cdot 9(4 \cdot 4)$ & $66 \cdot 8(3 \cdot 7)$ & $66 \cdot 1(2 \cdot 8)$ \\
QS 1 & $491(8 \cdot 9)$ & $484(5.4)$ & $482(6 \cdot 5)$ & $485(5 \cdot 6)$ \\
$\begin{array}{l}\text { Systolic blood } \\
\text { pressure }\end{array}$ & $119(2 \cdot 7)$ & $119(2 \cdot 2)$ & $122(1 \cdot 6)$ & $123(2 \cdot 3)$ \\
$\begin{array}{l}\text { Diastolic blood } \\
\text { pressure }\end{array}$ & $77 \cdot 4(2 \cdot 8)$ & $74 \cdot 8(1 \cdot 9)$ & $77 \cdot 9(2 \cdot 1)$ & $78 \cdot 9(2 \cdot 1)$ \\
QTc & $398(5 \cdot 9)$ & $384(5 \cdot 4)$ & $389(5 \cdot 6)$ & $387(4 \cdot 2)$ \\
\hline
\end{tabular}

No significant differences between treatment groups.

$\mathrm{QS}_{2} \mathrm{I}-\mathrm{QS}_{2}$ (total electromechanical systole) corrected for heart rate. 
Table 2 Effect of inhaling increasing doses of placebo, fenoterol (Fen), isoprenaline (Isop), and salbutamol (Salb) on the heart rate and $Q S_{2}$ index (mean (SEM) values)

\begin{tabular}{|c|c|c|c|c|c|c|c|c|c|}
\hline \multirow[b]{2}{*}{ Time (min) } & \multirow[b]{2}{*}{ Dose ( $\mu \mathrm{g})$} & \multicolumn{4}{|c|}{ Heart rate (beats/min) } & \multicolumn{4}{|c|}{$Q S_{2}$ index (ms) } \\
\hline & & Placebo & Fen & Isop & Salb & Placebo & Fen & Isop & Salb \\
\hline $\begin{array}{r}5 \\
15\end{array}$ & 400 & $\begin{array}{l}-2 \cdot 2(1.4) \\
-2.2(1.5)\end{array}$ & $\begin{array}{l}4 \cdot 5^{*}(2 \cdot 1) \\
5 \cdot 6+(2 \cdot 0)\end{array}$ & $\begin{array}{l}5+(2 \cdot 9) \\
0.6(2 \cdot 6)\end{array}$ & $\begin{array}{l}3.4(1.3) \\
1.5(1.0)\end{array}$ & $\begin{array}{l}1.8(1.5) \\
3.4(2.7)\end{array}$ & $\begin{array}{l}-6 \cdot 9(2 \cdot 1) \\
0(2 \cdot 2)\end{array}$ & $\begin{array}{l}-14.4 \dagger(3.4) \\
1.4(2 \cdot 1)\end{array}$ & $\begin{array}{l}-6 \cdot 3(2 \cdot 8) \\
-2 \cdot 1(2 \cdot 0)\end{array}$ \\
\hline $\begin{array}{l}20 \\
30\end{array}$ & 000 & $\begin{array}{l}-2 \cdot 2(1 \cdot 6) \\
-4 \cdot 1(1 \cdot 9)\end{array}$ & $\begin{array}{l}14 \cdot 3+(1 \cdot 5) \\
11 \cdot 2+(2 \cdot 4)\end{array}$ & $\begin{array}{l}7 \cdot 3+(3 \cdot 2) \\
2 \cdot 8+(2 \cdot 8)\end{array}$ & $\begin{array}{l}3.9(1.5) \\
2.9+(1.9)\end{array}$ & $\begin{array}{l}6.7(2 \cdot 1) \\
8.4(2 \cdot 4)\end{array}$ & $\begin{array}{l}-22.4+(3.2) \\
-15.6+(3.7)\end{array}$ & $\begin{array}{l}-26+(3.7) \\
-5.9+(3.6)\end{array}$ & $\begin{array}{l}-11 \cdot 5+(3 \cdot 2) \\
-8 \cdot 2 \dagger(3 \cdot 0)\end{array}$ \\
\hline $\begin{array}{l}35 \\
45\end{array}$ & & $\begin{array}{l}-3.0(2.5) \\
-5.6(2.5)\end{array}$ & $\begin{array}{l}16.9+(2.6) \\
19 \cdot 3+(2 \cdot 4)\end{array}$ & $\begin{array}{l}6.9 \dagger(2.5) \\
0.3 *(3.0)\end{array}$ & $\begin{array}{l}4 \cdot 1 \dagger(1 \cdot 7) \\
8 \cdot 2+(2 \cdot 4)\end{array}$ & $\begin{array}{l}9 \cdot 1(2 \cdot 3) \\
11 \cdot 8(2 \cdot 8)\end{array}$ & $\begin{array}{l}-30 \cdot 0+(5 \cdot 8) \\
-28 \cdot 1+(4 \cdot 6)\end{array}$ & $\begin{array}{l}-31.4 \dagger(6 \cdot 1) \\
-9 \cdot 3 \dagger(1 \cdot 1)\end{array}$ & $\begin{array}{l}-13 \cdot 2+(4 \cdot 8) \\
-13 \cdot 1+(4 \cdot 4)\end{array}$ \\
\hline
\end{tabular}

With the Bonferroni correction $\mathrm{p}<0.0014$ is considered significant.

Beta agonists $v$ placebo: ${ }^{*} \mathrm{p}<0.0012 ; \mathrm{tp}<0.0006$.

Significant differences between beta agonists:

Heart rate: Fenoterol $v$ isoprenaline, and salbutamol, $20-45 \mathrm{~min}, \mathrm{p}<0.0006$

$Q S_{2}$ index: Fenoterol $v$ isoprenaline, at 30 and $45 \mathrm{~min}, \mathrm{p}<0.0011$; fenoterol $v$ salbutamol, 20, 35, and $45 \mathrm{~min}, \mathrm{p}<0.0003$; isoprenaline $v$ 을 salbutamol, 20 and $35 \mathrm{~min}, \mathrm{p}<0.0001$.

placebo, only fenoterol and salbutamol caused a significant decrease in plasma potassium. The maximum decrease after fenoterol $(-0.81 \mathrm{mmol} / \mathrm{l})$ was significantly greater than the corresponding fall after salbutamol $(-0.33 \mathrm{mmol} / \mathrm{l} ; \mathrm{p}<0.0001)$.

\section{Discussion}

We have shown that the repeated inhalation of fenoterol results in a maximum inotropic effect similar to that of an identical dose of isoprenaline, and that the chronotropic, electrocardiographic and hypokalaemic effects are of greater magnitude. The cardiovascular and hypokalaemic effects of fenoterol were significantly greater than those of equal doses of salbutamol.

To determine the inotropic effect of treatment, changes in $\mathrm{QS}_{2} \mathrm{I}$ and systolic blood pressure were measured. A decrease in $\mathrm{QS}_{2} \mathrm{I}$ is a reliable measure of a positive inotropic effect, and is a well documented response to isoprenaline. ${ }^{1920} \mathrm{QS}_{2} \mathrm{I}$ is invariably unchanged by afterload reduction alone. ${ }^{21}$ The inotropic responses observed in this study are most likely to be due to direct beta ${ }_{1}$ adrenoceptor stimulation, as shown by Strauss et al, ${ }^{22}$ who found that the inotropic effect of terbutaline was significantly attenuated by the beta $a_{1}$ selective antagonist atenolol. The maximum inotropic effect of fenoterol will represent a cumulative effect, since fenoterol is cleared much less rapidly than isoprenaline. The difference in inotropic effect between fenoterol and salbutamol indicates the greater beta $a_{1}$ adrenergic activity of fenoterol and supports earlier animal studies ${ }^{23}$ and more recent studies in normal subjects. ${ }^{13}$

The increase in heart rate after administration of the beta agonists in this study is likely to be due to a

Table 3 Effect of inhaling increasing doses of placebo, fenoterol, isoprenaline, and salbutamol on blood pressure (mean (SEM) values)

\begin{tabular}{|c|c|c|c|c|c|c|c|c|c|}
\hline \multirow[b]{2}{*}{ Time (min) } & \multirow[b]{2}{*}{ Dose ( $\mu \mathrm{g})$} & \multicolumn{4}{|c|}{ Systolic blood pressure ( $\mathrm{mm} \mathrm{Hg}$ ) } & \multicolumn{4}{|c|}{ Diastolic blood pressure ( $\mathrm{mm} \mathrm{Hg}$ ) } \\
\hline & & Placebo & Fen & Isop & Salb & Placebo & Fen & Isop & Salb \\
\hline & 400 & & & & & & & & \\
\hline $\begin{array}{r}5 \\
15\end{array}$ & & $\begin{array}{l}2.4(1 \cdot 3) \\
6 \cdot 6(2 \cdot 5)\end{array}$ & $\begin{array}{l}5.6(1.4) \\
6.6(3 \cdot 1)\end{array}$ & $\begin{array}{l}6 \cdot 3(2 \cdot 8) \\
1 \cdot 3(2 \cdot 1)\end{array}$ & $\begin{array}{l}0.9(1 \cdot 5) \\
0.6(2 \cdot 1)\end{array}$ & $\begin{array}{l}-2 \cdot 3(1 \cdot 6) \\
1 \cdot 5(1 \cdot 7)\end{array}$ & $\begin{array}{l}-7 \cdot 3(3 \cdot 8) \\
-2 \cdot 7(2 \cdot 3)\end{array}$ & $\begin{array}{l}-7.7(1.9) \\
-2.9(1.0)\end{array}$ & $\begin{array}{l}-9 \cdot 4(3 \cdot 7) \\
-8 \cdot 2 *(2 \cdot 4)\end{array}$ \\
\hline $\begin{array}{l}20 \\
30\end{array}$ & & $\begin{array}{l}5.2(1.6) \\
1.8(1.8)\end{array}$ & $\begin{array}{l}11 \cdot 5(2 \cdot 1) \\
14 \cdot 3 *(2 \cdot 8)\end{array}$ & $\begin{array}{l}9.6(3.1) \\
3.4(1.6)\end{array}$ & $\begin{array}{l}4.3(2.0) \\
3.9(1.9)\end{array}$ & $\begin{array}{l}5 \cdot 2(1 \cdot 6) \\
-2 \cdot 0(1 \cdot 4)\end{array}$ & $\begin{array}{l}-10 \cdot 1 *(2 \cdot 3) \\
-7 \cdot 5(3 \cdot 6)\end{array}$ & $\begin{array}{l}-9 \cdot 4^{*}(2 \cdot 1) \\
-6 \cdot 1(2 \cdot 3)\end{array}$ & $\begin{array}{l}-8.1(3.3) \\
-8.4(2.3)\end{array}$ \\
\hline $\begin{array}{l}30 \\
45\end{array}$ & 00 & $\begin{array}{l}0.8(0.8) \\
2.1(1.6)\end{array}$ & $\begin{array}{l}16 \cdot 7^{*}(4 \cdot 4) \\
14 \cdot 1 *(3 \cdot 3)\end{array}$ & $\begin{array}{l}14 \cdot 0^{*}(3.6) \\
5 \cdot 7(2 \cdot 9)\end{array}$ & $\begin{array}{l}8 \cdot 8^{*}(2 \cdot 2) \\
7 \cdot 2(1 \cdot 6)\end{array}$ & $\begin{array}{l}0.9(1 \cdot 9) \\
4 \cdot 5(2 \cdot 3)\end{array}$ & $\begin{array}{l}-11 \cdot 2 *(2 \cdot 6) \\
-9 \cdot 5^{*}(1 \cdot 2)\end{array}$ & $\begin{array}{l}-11.9 *(1.5) \\
-0.9(2 \cdot 1)\end{array}$ & $\begin{array}{l}-11 \cdot 1 *(3 \cdot 7) \\
-10 \cdot 4 *(2 \cdot 8)\end{array}$ \\
\hline
\end{tabular}

With the Bonferroni correction $\mathrm{p}<0.0014$ is considered significant.

Beta agonists $v$ placebo: ${ }^{*} \mathrm{p}<0.0008-<0.0001$.

Significant differences between beta agonists:

Systolic blood pressure: Fenoterol $v$ isoprenaline, $30 \mathrm{~min}, \mathrm{p}<0.0001$; fenoterol $v$ salbutamol, $20-45 \mathrm{~min}$, p $<0.0014$; isoprenaline $v$ salbutamol, $35 \mathrm{~min}, \mathrm{p}<0.0005$.

Diastolic blood pressure: Fenoterol and salbutamol $v$ isoprenaline, $45 \mathrm{~min}, \mathrm{p}<0.0013$. 


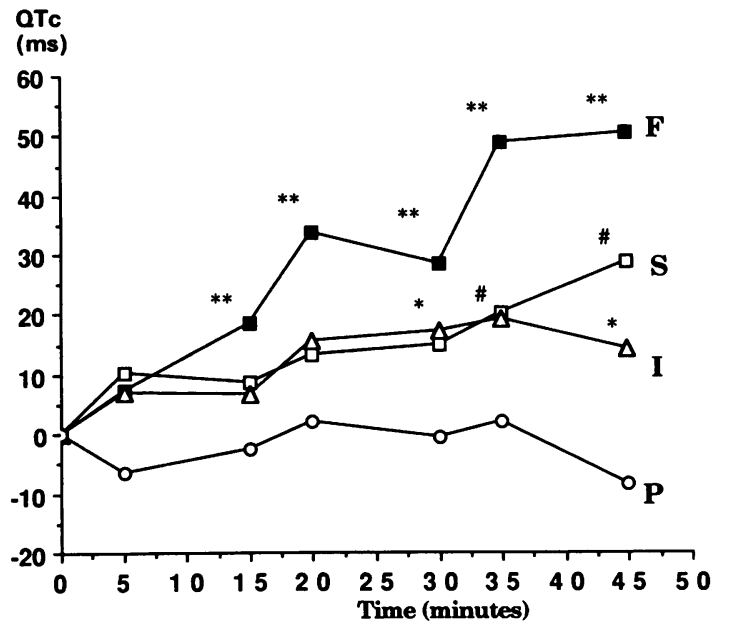

Fig 1 Effect of inhalation of increasing doses of fenoterol $(F)$, isoprenaline $(I)$, salbutamol $(S)$ and placebo $(P)$ on QTc.

${ }^{*} p<0.0011, * p<0.001,{ }^{* *} p<0.0001$ versus placebo with Bonferroni correction $p<0.0028$ considered significant.

combination of beta ${ }_{1}$ and beta ${ }_{2}$ adrenoceptor stimulation. Regardless of the mechanism, an increase in heart rate combined with an increase in inotropy will result in increased myocardial oxygen consumption, which in the face of hypoxaemia may be deleterious. ${ }^{24}$

It has been previously found that beta ${ }_{2}$ adrenergic agonists cause hypokalaemia owing to a direct cellular uptake of potassium through increased $\mathrm{Na}-\mathrm{K}$ ATPase activity. ${ }^{25}$ Our observations that the reduction in plasma potassium due to fenoterol was more than double that of salbutamol is in keeping with the study
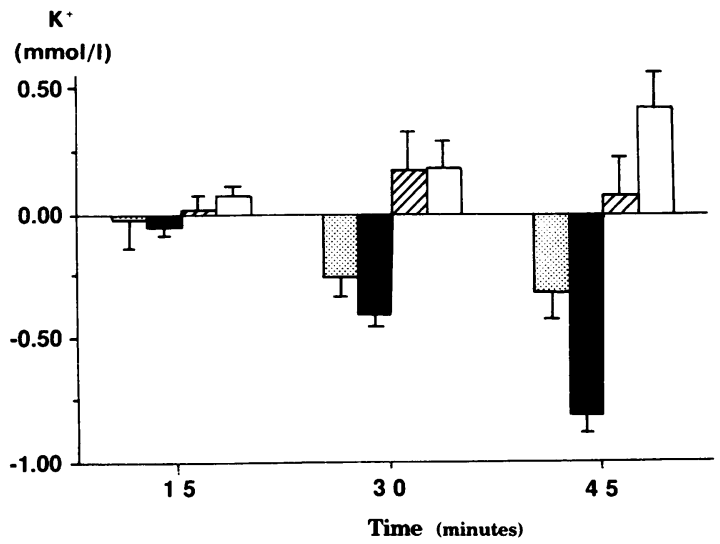

Fig 2 Effect of inhalation of increasing doses of salbutamol ( $)$,fenoterol ( $\square$ ) isoprenaline $(\square)$, and placebo ( $\square$ ) on plasma potassium concentration. ${ }^{*} p<0.0001$; with Bonferroni correction $p<0.0014$ considered significant. of Scheinin et $a l^{13}$ and provides further evidence that there are significant differences in the pharmacodynamic effects of these two agents when given in equal doses.

Both hypokalaemia and beta adrenergic stimulation are associated with electrophysiological changes in cardiac muscle. In this study fenoterol caused a significantly greater prolongation of the QTc interval than either isoprenaline or salbutamol. QTc prolongation may be associated with ventricular dysrhythmias, ${ }^{26}$ and Tandon has shown that repeated inhalation of fenoterol was associated with a greater frequency of ventricular ectopic beats than equivalent doses of salbutamol. ${ }^{27}$

It could be argued that both the doses and the dosing interval that we have used are excessive and certainly they exceed the manufacturers recommended ranges. In the context of acute severe asthma relatively unresponsive to bronchodilator treatment, however, we believe that such self administered doses may be used.

In summary, we have shown that repeated inhalation of fenoterol in normal volunteers results in significantly greater cardiovascular and hypokalaemic effects than the same doses of salbutamol while being similar in its maximum inotropic effect to isoprenaline. The relevance of these findings in patients with severe asthma remains to be clarified.

We thank Mr R Siebers for the measurements of plasma potassium, and Mr G Purdie for statistical advice.

\section{References}

1 Speizer FE, Doll R, Heaf P, Strang LB. Investigation into use of drugs preceding death from asthma. $\mathrm{Br} \mathrm{Med} \mathrm{J}$ 1968;i:339-43.

2 Keating G, Mitchell EA, Jackson RT, Beaglehole R, Rea $\mathrm{HH}$. Trends in sales of drugs for asthma in New Zealand, Australia and the United Kingdom 1975-81. Br Med J 1984;289:348-51.

3 Paterson JW, Woolcock AJ, Shenfield GM. Bronchodilator drugs. Am Rev Respir Dis 1979;120: 1149-88.

4 Banner AS, Sunderrajan EV, Agarwal MK, Addington WW. Arrhythmogenic effects of orally administered bronchodilators. Arch Intern Med 1979;139:434-7.

5 Higgins RM, Cookson WOCM, Lane DJ, John SM, McCarthy GL, McCarthy ST. Cardiac arrhythmias caused by nebulised beta-agonist therapy. Lancet 1987;ii:863-4.

6 Adverse Drug Reactions Advisory Committee. Med J Aust 1979;ii:92.

7 Neville E, Corris PA, Vivian J, Nariman S, Gibson GJ. Nebulised salbutamol and angina. $B r$ Med $J$ 1982; 285:796-7.

8 Sears MR. Why are deaths from asthma increasing? Eur $J$ Respir Dis 1986;69(suppl147):175-81. 
9 O'Donnell TV, Asher MI, Mitchell EA, Sears MR. Review of asthma in New Zealand. Wellington: Asthma Foundation of New Zealand, 1987:12-3.

10 Recommendations of the Asthma Mortality Task Force. J Allergy Clin Immunol 1987;80:364-6.

11 Chapman KR, Smith DL, Rebuck AS, Leenen FH. Hemodynamic effects of an inhaled beta-2 agonist. Clin Pharmacol Ther 1984;35:762-7.

12 Haalboom JRE, Deenstra M, Struyrenberg A. Hypokalaemia induced by inhalation of fenoterol Lancet 1985; i:1125-7.

13 Scheinin $\mathbf{M}$, Koulu $\mathbf{M}$, Laurikainen $\mathrm{E}$, Allonen $\mathrm{H}$. Hypokalaemia and other non-bronchial effects of inhaled fenoterol and salbutamol: a placebo-controlled dose-response study in healthy volunteers. $\mathrm{Br} \mathrm{J}$ Clin Pharmacol 1987;24:645-53.

14 Burgess CD, Turner P, Warrington SJ, Cardiovascular responses to mianserin hydrochloride: a comparison with tricyclic antidepressants. $\mathrm{Br} J$ Clin Pharmacol 1978;5(suppl):21-8.

15 Burgess $\mathrm{CD}$. The investigation of the cardiovascular effects of antidepressant drugs using non-invasive techniques. MD thesis, University of Cape Town, 1981.

16 Bazett HC. An analysis of the time relations of the electrocardiogram. Heart 1920;7:353-70.

17 Winer BJ. Statistical principles in experimental design. 2nd ed. New York: McGraw-Hill, 1971:549.

18 Wallenstein S, Zucker CL, Fleiss JL. Some statistica methods useful in circulation research. Circulation 1980;47:1-9.
19 Lewis RP, Rittgers SE, Forester WF, Boudoulas H. A critical review of the systolic time intervals. Circulation 1977;56:146-58.

20 Conrad KA, Effects of atropine on diastolic time. Circulation 1981;63:371-7.

21 Hassan S, Turner P. Systolic time intervals: a review of the method in the non-invasive investigation of cardiac function in health, disease and clinical pharmacology. Postgrad Med J 1983;59:423-34.

22 Strauss MH, Reeves RA, Smith DL, Leenen FH. The role of cardiac beta-1 receptors in the hemodynamic response to a beta-2 agonist. Clin Pharmacol Ther 1986;40:108-15

23 Brittain RT, Dean CM, Jack D. Sympathomimetic bronchodilator drugs. Pharmacology and Therapeutics Bulletin 1976;2:423-62.

24 Livesay JJ, Follette DM, Fey KH, et al. Optimising myocardial supply demand balance with alpha adrenergic drugs during cardiopulmonary resuscitation. $J$ Thorac Cardiovasc Surg 1978;76:244-51.

25 Clausen T, Flatman JA. Beta 2 adrenoreceptors mediate the stimulating effect of adrenaline on active electrogenic $\mathrm{Na}-\mathrm{K}$ transport in rat soleus muscle. $\mathrm{Br} \mathrm{J}$ Pharmacol 1980; 68:749-55.

26 Krikler DM, Curry PVL. Torsade de pointes, an atypical $\vec{\oplus}$ ventricular tachycardia. $B r$ Heart $J$ 1976; 38:117-20.

27 Tandon MK. Cardiopulmonary effects of fenoterol and salbutamol aerosols. Chest 1980;77:429-31. 